\title{
A microsatellite based method for quantification of fungi in decomposing plant material elucidates the role of Fusarium graminearum DON production in the saprophytic competition with Trichoderma atroviride in maize tissue microcosms
}

\author{
Andreas Naef, Mauro Senatore \& Geneviève Défago \\ Institute of Plant Sciences, Phytopathology group, Swiss Federal Institute of Technology, Zurich, Switzerland
}

\author{
Correspondence: Geneviève Défago, \\ Phytopathology Group, Institute of Plant \\ Sciences, Swiss Federal Institute of \\ Technology, Universitätstrasse 2, CH-8092 \\ Zurich, Switzerland. Tel.: +41446323869; \\ fax: +41 4463215 72; e-mail: \\ genevieve.defago@ipw.agrl.ethz.ch
}

Received 23 May 2005; revised 13 July 2005; accepted 7 August 2005.

First published online 6 October 2005.

doi:10.1111/j.1574-6941.2005.00023.x

Editor: Paul Rainey

Keywords

biological control; competitive PCR; deoxynivalenol; microsatellite; Fusarium; Trichoderma.

\begin{abstract}
Common PCR assays for quantification of fungi in living plants cannot be used to study saprophytic colonization of fungi because plant decomposition releases PCR-inhibiting substances and saprophytes degrade the plant DNA which could serve as internal standard. The microsatellite PCR assays presented here overcome these problems by spiking samples prior to DNA extraction with mycelium of a reference strain. PCR with fluorescent primers co-amplifies microsatellite fragments of different length from target and reference strains. These fragments were separated in a capillary sequencer with fluorescence detection. The target/reference ratio of fluorescence signal was used to calculate target biomass in the sample. Such PCR assays were developed for the mycotoxin deoxynivalenol (DON)-producing wheat and maize pathogen Fusarium graminearum and the biocontrol agent Trichoderma atroviride, using new microsatellite markers. In contrast to real-time PCR assays, the novel PCR assays showed reliable fungal biomass quantification in samples with differentially decomposed plant tissue. The PCR assays were used to quantify the two fungi after competitive colonization of autoclaved maize leaf tissue in microcosms. Using a DON-producing F. graminearum wild-type strain and its nontoxigenic mutant we found no evidence for a role of DON production in F. graminearum defense against T. atroviride. The presence of T. atroviride resulted in a $36 \%$ lower wild-type DON production per biomass.
\end{abstract}

\section{Introduction}

Fusarium head blight of small grain cereals is a re-emerging disease in many cereal growing regions around the world (McMullen et al., 1997). One of the predominant species associated with Fusarium head blight is Fusarium graminearum Schwabe [teleomorph Gibberella zeae (Schwabe Petch), (Bottalico \& Perrone, 2002)]. Many isolates of F. graminearum have been found to produce the mycotoxin deoxynivalenol (DON) (Bottalico \& Perrone, 2002), which is commonly found in barley, maize, rye, wheat and mixed feed (Bennett \& Klich, 2003). Fusarium graminearum survives on decomposing plant material present after crop harvest, particularly from maize (Windels \& Kommedahl, 1984; Dill-Macky \& Jones, 2000), which serves as inoculum source for subsequent crops, e.g. wheat (Sutton, 1982).
Trichoderma spp. aggressively colonize crop residues of maize and wheat throughout the decomposition process (Broder \& Wagner, 1988). They have been used successfully for biological control of a wide range of soil and residue borne plant pathogens (Hjeljord \& Tronsmo, 1998). Inoculation of wheat and black oat straw with Trichoderma resulted in a reduced F. graminearum incidence (Fernandez, 1992), making Trichoderma a promising candidate to control the survival of F. graminearum on crop residues. However, a recent study has shown that the mycotoxin deoxynivalenol (DON) down-regulates the nag1 chitinase gene, which may be involved in the biocontrol activity of Trichoderma atroviride Karsten strain P1 (Lutz et al., 2003) (teleomorph =Hypocrea atroviridis, Dodd et al., 2003), suggesting that DON production plays a role in the defense of F. graminearum against this antagonist. To establish a 
Trichoderma mediated disease control, the role of DON production will have to be determined.

To investigate this factor in the interaction between Trichoderma and Fusarium, a method for biomass quantification of each fungus is needed, in addition to the already established DON quantification with ELISA (Lutz et al., 2003). PCR assays that have been developed to quantify toxigenic Fusarium in infected plant parts (competitive PCR, Nicholson et al., 1998; Edwards et al., 2001 and real-time PCR, Schnerr et al., 2001; Bluhm et al., 2004; Reischer et al., 2004; Waalwijk et al., 2004) are not suitable for studying saprophytic competition among fungi on plant tissue because they assume constant efficiency of target DNA extraction and PCR amplification. This is inappropriate for plant material colonized by saprophytes because the decomposition process releases substances that inhibit PCR amplification (Wilson, 1997). Coamplification of specific plant DNA sequences (Winton et al., 2002) cannot serve as an internal standard for PCR inhibition because plant DNA is degraded by saprophytes. Furthermore, the assumption of constant DNA extraction efficiency is questionable in samples with changing composition. Normalization of total DNA, a common approach to standardize variability in DNA extraction (Nicholson et al., 1998; Edwards et al., 2001), is inapplicable because plant DNA declines. In all competitive PCR assays, added DNA is used as internal standard for inhibitory effects in PCR amplification (Nicholson et al., 1998; Edwards et al., 2001), but these assays still lack a standard for variation in the DNA extraction because the artificially constructed competitor DNA is added after DNA extraction.

The novel method presented here is based on PCR of a microsatellite. Microsatellites are composed of simple sequence repeats found in all eukaryotic organisms ( $\mathrm{Li}$ et al., 2002). For the development of microsatellite markers, sequences with simple sequence repeats must be identified in a genome database or a repeat-enriched clone library. Specific primers are then designed on flanking regions of the repeats. Many microsatellites contain a variable number of repeats in different individuals, resulting in length polymorphism of the amplified fragment commonly used in population genetic studies (Tenzer et al., 1999) but in our case, for a competitive PCR.

The aim of this study was to develop a robust method for quantification of fungi in samples with decomposing plant material. The PCR assays presented here for the DONproducing plant pathogen F. graminearum and the biocontrol agent $T$. atroviride are based on spiking samples with mycelium of a closely related reference strain and competitive amplification of differently sized microsatellite alleles. These assays make it possible to investigate the role of F. graminearum DON biosynthesis in the colonization of sterilized maize leaf tissue in competition with the biocontrol agent $T$. atroviride.

\section{Materials and methods}

\section{Fungal strains and culture conditions}

Trichoderma atroviride strain P1 is an isolate from wood chips and was classified for a long time as Trichoderma harzianum ATCC 74058 based on morphological features. However, DNA sequence analysis has shown that it is more closely related with T. atroviride (Kullnig et al., 2001). Trichoderma harzianum strain RAC616 is a Swiss isolate and was used as reference in the PCR assay. Trichoderma strains were stored as a spore suspension in $20 \%(\mathrm{v} / \mathrm{v})$ glycerol at $-20{ }^{\circ} \mathrm{C}$. Fusarium graminearum strain GZ3639 was isolated from scab-infected wheat in the midwest United States (Proctor et al., 1995). Fusarium graminearum strain GZT40 is a derivate of GZ3639 that contains the transformation vector pGZTS4-, which disrupts the tri5 gene and eliminates DON production (Proctor et al., 1995). Fusarium graminearum strain 9701 is a Swiss isolate from wheat and was used as reference in the PCR assay. Fusarium graminearum strains were stored on $1.5 \%$ malt extract (Oxoid, Hampshire, UK) agar slants at $3{ }^{\circ} \mathrm{C}$. For mycelium production, Trichoderma strains were grown for 7 days in $250 \mathrm{~mL} 1 / 5 \mathrm{PDB}$ [ $4.8 \mathrm{~g}$ potato dextrose broth (Difco, Detroit, MI, USA), pH 6.5] on a shaker at 180 r.p.m. at $24^{\circ} \mathrm{C}$ in darkness. Fusarium strains were grown under the same conditions in $1.5 \%$ malt extract (Oxoid). For inoculation of experiments, the fungi were grown for 5 days on agar plates [12 g agar (Oxoid)] with the same media at $24^{\circ} \mathrm{C}$ in darkness.

\section{Development of microsatellites}

A sequence database (Syngenta, Torrey Mesa Research Institute, San Diego, CA) of the F. graminearum genome was screened for simple sequence repeats. Oligonucleotide primers for PCR amplification were designed on the flanking regions of repeats with the online service 'Primer3' (Rozen \& Skaletskyand, 2000). Specificity and length polymorphism were tested with DNA of closely related and other organisms (Table 1). Because of high costs of fluorescent primer construction, primer screening was performed with $\left[\gamma^{-33} \mathrm{P}\right]$ ATP-labeled forward primer (Amersham Biosciences, Uppsala, Sweden) under conditions as described by Tenzer et al. (1999). PCR products were analyzed on a $6 \%$ denaturing acrylamide gel (National Diagnostic, Atlanta, GA) and visualized with an X-ray film [X-Omat AR (Eastman Kodak Company, Rochester, NY)]. To find simple sequence repeats in the genome of $T$. atroviride, two repeat enriched clone libraries (with TG and TC repeats) were constructed with genomic DNA of strain P1 using a previously described protocol (Tenzer et al., 1999). Clones with repeat inserts were identified with a Southern dot blot 
Table 1. Characteristics, specificity, and alleles of microsatellites used in this study

\begin{tabular}{|c|c|c|}
\hline & Fusarium graminearum microsatellite, MS-Fg103 & Trichoderma atroviride microsatellite, MS-Ta4 \\
\hline Sequence primer fwd & 5'-GGTATCCGTACAACCCGATG-3' & 5'-ATCTGGCACTGCTTGGTAGG-3' \\
\hline Sequence primer rev & 5'-TTCTTTGATTTGGACCGAGG-3' & 5'-TCGATCGCCTTCGTATTAGG-3' \\
\hline Repeats & TG & TC \\
\hline Source & Sequence database* & Enriched clone library for TC repeats \\
\hline \multicolumn{3}{|l|}{ Alleles (bp) in different organisms: } \\
\hline Fusarium graminearum (20 strains) & $225,227, \mathbf{2 2 9}^{\dagger}, 233,235,237, \mathbf{2 4 1}, 257,263$ & No amplification \\
\hline Fusarium culmorum (20 strains) & 221 & No amplification \\
\hline Fusarium crookwellense (five strains) & 219 & Not determined \\
\hline Fusarium sambucinum (one strain) & 267 & Not determined \\
\hline Fusarium acuminatum (three strains) & No amplification & Not determined \\
\hline Fusarium avenaceum (three strains) & No amplification & Not determined \\
\hline Fusarium poae (two strains) & No amplification & Not determined \\
\hline Fusarium verticilloides (three strains) & No amplification & Not determined \\
\hline Fusarium oxysporum (two strains) & No amplification & Not determined \\
\hline Trichoderma atroviride (one strain) & No amplification & 132 \\
\hline Trichoderma harzianum (four strains) & No amplification & 132,142 \\
\hline Trichoderma album (three strains) & Not determined & 132 \\
\hline Microdochium nivale D54 & No amplification & No amplification \\
\hline Pseudomonas fluorescens CHAO & No amplification & No amplification \\
\hline Maize (two varieties) & No amplification & No amplification \\
\hline
\end{tabular}

*The microsatellite marker MS-Fg103 was derived from the F. graminearum genome database of the Torrey Mesa Research Institute, San Diego, CA (Syngenta). The sequence was also found in contig 1.224 of the genome sequence of Gibberella zeae strain PH-1 deposited in GenBank with accession number AACM01000224.

${ }^{\dagger}$ Alleles in bold face were used in the competitive microsatellite PCR assays.

(Tenzer et al., 1999) and sequenced with M13 universal primers by Synergene Biotech GmbH (Zurich, Switzerland). Primer design and test PCRs were performed as described above for F. graminearum.

\section{Preparation of samples and DNA extraction}

Samples of microcosm experiments were freeze dried and weighted in $2 \mathrm{~mL}$ reaction tubes using a microbalance accurate to $0.01 \mathrm{mg}$. To each sample, $2.5 \mathrm{mg}$ freeze-dried mycelium of F. graminearum strain 9701 and $2.5 \mathrm{mg}$ freezedried mycelium of T. harzianum strain RAC616 were added. Samples were then homogenized with glass balls in a Fastprep FP120 machine (Savant, Holbrook, NY) for $30 \mathrm{~s}$ at maximum level. DNA was extracted with the DNeasy Plant mini kit following the protocol of the manufacturer (Qiagen, Hilden, Germany) except for a 50\% increase of the cell lysis buffer volume and adaptation of the volumes in subsequent steps.

\section{Competitive microsatellite PCR and fragment analysis}

PCR with microsatellite MS-Fg103 or MS-Ta4 was performed in a $10 \mu \mathrm{L}$ volume containing $5 \mu \mathrm{L}$ of $1: 50$ diluted DNA extract, $1 \times$ reaction buffer (Amersham Biosciences), $0.1 \mathrm{mM}$ of each dNTP, $0.2 \mu \mathrm{M}$ of forward and reverse primer
(Table 1), and $1 \mathrm{U}$ of Taq polymerase (New England BioLabs, Beverly, MA). One quarter of the forward primer was dye-labeled [Beckman D4 dye for MS-Ta4, Beckman D3 dye for MS-Fg103 (Beckman-Coulter, Fullerton, CA)]. PCR was carried out in a T1-Thermoblock (Biometra, Göttingen, Germany) under the following conditions: $5 \mathrm{~min}$ at $94^{\circ} \mathrm{C}$ for denaturation, 35 cycles of $30 \mathrm{~s}$ at $94^{\circ} \mathrm{C}, 30 \mathrm{~s}$ at $60^{\circ} \mathrm{C}$, and $60 \mathrm{~s}$ at $72^{\circ} \mathrm{C}$, with a final extension of $10 \mathrm{~min}$ at $72^{\circ} \mathrm{C}$. For each sample, $1.5 \mu \mathrm{L}$ MS-Ta 4 PCR product and $3 \mu \mathrm{L}$ of MSFg103 PCR product were pooled in $20 \mu \mathrm{L}$ deionized water. After purification with Sephadex G-50 (Amersham Biosciences), $1 \mu \mathrm{L}$ of the CEQ DNA size standard 400 (Beckman-Coulter) was added. DNA fragments were separated by capillary electrophoresis and detected with laser-induced fluorescence in a CEQ 2000XL DNA analysis system (Beckman-Coulter), and analyzed with the software provided by Beckman-Coulter (version 4.2.0). The average peak height ratio from two replicate PCR assays was used to calculate the target/reference PCR products ratio for each microsatellite.

\section{Calibration of competitive PCR assays}

For each PCR assay, external standards were prepared in triplicate. Freeze-dried mycelia of the target strains (F. graminearum GZ3639 and T. atroviride $\mathrm{P} 1)$ were mixed with freeze-dried mycelium of the reference strains (F. graminearum 9701 and T. harzianum RAC616) in ratios of $1: 8,1: 4$, 
$1: 2,1: 1,2: 1,4: 1$ and $1: 8$ in a total of $30 \mathrm{mg}$ weight. DNA extraction and competitive microsatellite PCR were done as described above. The measured target/reference PCR products ratio was displayed on a logarithmic scale against the known mycelium ratio. A linear regression was performed on the data points from MS-Fg103 and MS-Ta4, respectively, with the program SYSTAT, version 10 (Systat Inc., Evanston, IL).

\section{Comparison with real-time PCR}

Six mg freeze-dried mycelium of F. graminearum GZ3639 or T. atroviride P1 were mixed with $24 \mathrm{mg}$ nontarget material composed of autoclaved maize leaves, air-dried maize leaves, lyophilized mycelium of the other fungus (T. atroviride P1 or F. graminearum GZ3639), or nonsterile maize stalks collected in spring from the soil surface. Three replicates of each mixture and three replicates of $6 \mathrm{mg}$ pure mycelium were spiked with reference mycelium and assayed in separate competitive microsatellite PCR assays. Three identical replicates were analyzed with real-time PCR using our new microsatellite primers (Table 1) and the DNA binding dye SYBR ${ }^{\circledR}$ Green. For these assays, DNA was extracted without prior addition of reference mycelium and DNA was quantified in triplicates of $1: 100$ diluted extracts with PicoGreen ${ }^{\circledR}$ (Molecular Probes Europe, Leiden, the Netherlands) according to the manufacturer's recommendations using a SPECTRAFluor Plus instrument (Tecan, Männedorf, Switzerland). Real-time PCR was performed in a $15 \mu \mathrm{L}$ volume containing $5 \mu \mathrm{L}$ of $1: 100$ diluted DNA extract, $1 \times$ SYBR $^{\circledR}$ Green PCR Master Mix (Applied Biosystems, Foster City, CA, USA), $0.2 \mu \mathrm{M}$ of forward and reverse primers. Cycling was done in an ABI Prism 7700 apparatus (Applied Biosystems) under the same conditions as described for the competitive microsatellite PCR. The replicates were quantified in separate real-time PCR assays. A serial dilution $(1: 50,1: 100,1: 200,1: 400$, and $1: 800)$ of the DNA extracts from $6 \mathrm{mg}$ pure mycelium of $F$. graminearum GZ3639 and T. atroviride P1 was included for calibration of each assay. Fisher's LSD test (sYSTAT) was used to compare the means of the recovered biomass from different mixtures and the means of DNA yield from mixtures without reference mycelium.

\section{Role of Fusarium graminearum DON production in interaction with the antagonist Trichoderma atroviride}

The early maturing maize hybrid Fuxxol (RAGT Semences, Rodez, France) was grown on an experimental field of Agroscope FAL Reckenholz (Zurich, Switzerland) in 2003. At tasseling stage, the 5 th leaf from the top was collected from 20 randomly selected maize plants. From each leaf, six rectangular pieces $(76 \times 26 \mathrm{~mm})$ were cut. The leaf pieces were stored at $-20{ }^{\circ} \mathrm{C}$ until use. For each experiment, 30 leaf pieces were placed on microscopy slides with the adaxial side down. Each leaf piece was fixed on the short sides with stainless paper clips and put on wetted filter-paper in a glass Petri dish and autoclaved at $120^{\circ} \mathrm{C}$ for $20 \mathrm{~min}$. Test trials with nonsterile leaves have shown that the natural microflora varies among leaf pieces, which affected the growth of our target fungi. Autoclaving was performed to obtain reproducible results, although the sterilization could have an effect on the interaction between the inoculated fungi. Pieces from one leaf were assigned randomly to one of the following treatments:

1 T. atroviride $\mathrm{P} 1$

2 F. graminearum GZ3639

3 F. graminearum GZT40

4 T. atroviride P1 and F. graminearum GZ3639

5 T. atroviride $\mathrm{P} 1$ and F. graminearum GZT40

6 No inoculation.

For treatments 4 and 5, pieces of agar $(8 \times 4 \mathrm{~mm})$ from plates with actively growing $T$. atroviride and F. graminearum were placed inverted at opposite sides of the leaf piece ( $5 \mathrm{~cm}$ from each other). For treatments $1-3$, only one agar plug was placed at the same place on the leaf piece. After 10 days of growth at $24{ }^{\circ} \mathrm{C}$ in $100 \%$ humidity in the dark, the centre square of the leaf piece was cut out and transferred to a $2 \mathrm{~mL}$ reaction tube. For determination of DON content, $1 \mathrm{~mL}$ of sterile distilled water was added to each tube. After the tubes were shaken horizontally for $2 \mathrm{~h}$ at 200 r.p.m., they were centrifuged for $2 \mathrm{~min}$ at maximum speed in a microcentrifuge. DON levels were quantified in the supernatant using ELISA as described below. The samples with the remaining supernatant were frozen at $-80{ }^{\circ} \mathrm{C}$ and freeze dried. Fungal biomasses were quantified with competitive microsatellite PCR as described above using microsatellite MS-Fg103 for F. graminearum strains and microsatellite MS-Ta4 for T. atroviride P1. DON production by F. graminearum was calculated for individual microcosms relative to the biomass of the F. graminearum strain. Data from three trials with six replicates each were pooled after no significant trial $\times$ treatment interaction was determined in a preliminary GLM analysis $(P=0.944$ for $F$. graminearum biomass, $P=0.242$ for $T$. atroviride biomass, $P=0.272$ for DON levels, and $P=0.223$ for DON production) (sYSTAT). Means were compared with Fisher's LSD test.

\section{DON quantification}

DON levels were quantified in $50 \mu \mathrm{L}$ of a $1: 10$ dilution of the aqueous sample extracts (see above) using a commercial enzyme-linked immunosorbent assay [Ridascreen Fast DON (R-Biopharm, Darmstadt, Germany)]. If necessary, the extracts were further diluted to fall into the range of 
calibrators and measured again. The test detects DON and 3 -acetyl DON with equal sensitivity down to $0.2 \mu \mathrm{gg}^{-1}$ and has negligible cross reactivity with DON-related substances such as nivalenol, 15-acetyl-DON, triacetyl-DON, triacetylnivalenol, tetra-acetyl-DON, and fusarenon $\mathrm{X}$.

\section{Results and discussion}

\section{Microsatellites}

Screening of a genome database of Fusarium graminearum available through the Torrey Mesa Research Institute (Syngenta) revealed more than 200 loci with simple sequence repeats (SSR). Primers were designed on the flanking regions of 21 sequences containing more than seven repeats. The primer pair MS-Fg103 was selected because it amplified a single DNA fragment of variable length without considerable stutter (Fig. 1). Stutter fragments are characteristic for microsatellites and result from DNA polymerase slippage on simple sequence repeats (Daniels et al., 1998). Amplification of a single allele occurred with DNA of all tested strains of the haploid fungus F. graminearum and the closely related species Fusarium culmorum, Fusarium crookwellense and Fusarium sambucinum from the section Discolor but not with DNA of Fusarium strains from other sections or any other organism tested (Table 1). Of 12 alleles identified, two were used in the quantitative PCR assay: the allele $241 \mathrm{bp}$ (19 TC repeats), which is present in the trial strain F. graminearum GZ3639, and the allele 229 bp ( 13 TC repeats), which is present in the reference strain F. graminearum 9701. The microsatellite MS-Ta4 was developed from the repeat enriched genomic libraries of Trichoderma atroviride P1. All of

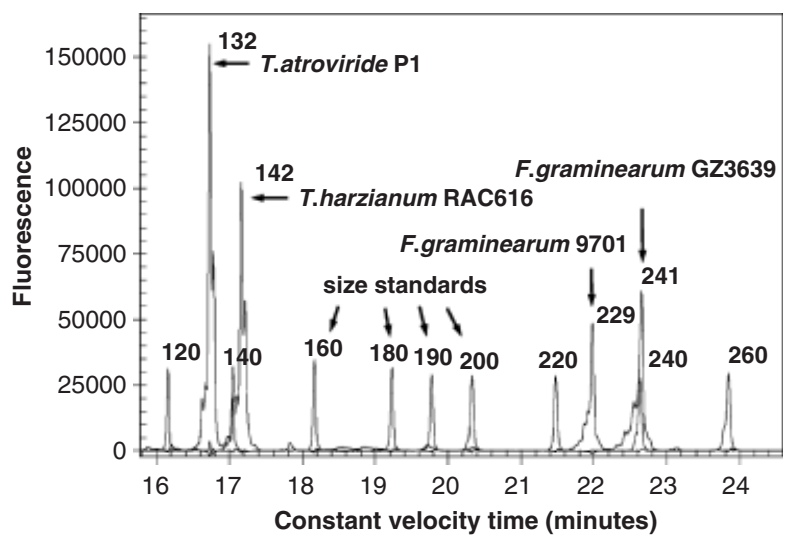

Fig. 1. Microsatellite PCR product analysis from a sample containing DNA of four fungal strains using a sequencer with capillary electrophoresis and laser-induced fluorescence detection. Peaks of Trichoderma strains represent the product of a competitive PCR with microsatellite MS-Ta4 and those of Fusarium strains represent products of a competitive PCR with microsatellite MS-Fg103. The two PCRs were done individually and pooled for fragment analysis. the 31 sequenced clones (17 from the TG library and 12 from the TC library) contained SSRs but some inserts were identical. In some other clones, the SSRs were too close to the cloning site to design PCR primers. Finally, eight primers were designed on sequences containing more then 10 repeats. The primer pair MS-Ta4 was selected because it generates a DNA fragment with little stutter (Fig. 1) of either 132 or $142 \mathrm{bp}$ for Trichoderma strains only (Table 1). The allele of $132 \mathrm{bp}$ (13 TG repeats) is present in T. atroviride P1, which was used in the microcosm experiments, and the allele $142 \mathrm{bp}$ (18 TG repeats) is present in T. harzianum RAC616, which serves as reference in the PCR assay.

\section{Competitive microsatellite PCR}

To test the use of microsatellites MS-Fg103 and MS-Ta4 for a competitive PCR, DNA was extracted from mycelium mixtures of a trial and a reference strain. A capillary sequencer was used to separate and quantify the fluorescently labeled, differently sized PCR products (Fig. 1). We found a linear correlation between biomass ratio of F. graminearum strains GZ3639 and 9701 and their MS-Fg103 PCR product ratio $\left(R^{2}=0.997, P<0.001\right.$, Fig. 2$)$ and also a linear correlation between the biomass ratio of $T$. atroviride $\mathrm{P} 1$ and $T$. harzianum RAC616 and their MS-Ta4 PCR product ratio $\left(R^{2}=0.995, P<0.001\right.$, Fig. 2). These correlations were used for the development of competitive PCR assays for the quantification of the trial strains F. graminearum GZ3639 and T. atroviride P1. Freeze-dried samples were spiked with freeze-dried mycelium of the closely related reference strains F. graminearum 9701 and T. harzianum RAC616, respectively. The biomass of trial strains was calculated from the PCR product ratio using the linear regression equations from standard mixtures and the known amount of reference biomass. Since a mutation in the DON synthetic pathway does not affect the microsatellite site, the MS-Fg103 PCR assay could also be used to quantify the F. graminearum strain GZT40 with interrupted DON synthesis (Proctor et al., 1995).

To our knowledge, a microsatellite locus has never been used for the development of a quantitative competitive PCR assay. Given the natural length polymorphism of these markers it was not necessary to construct an artificial competitor as in common competitive PCR. Instead, the differently sized microsatellite DNA of a closely related reference strain serves as competitor. As this competitor was added as mycelium before DNA extraction, it also works as an internal standard for variation in DNA extraction.

However, the microsatellites and the reference strains must be carefully selected because, firstly, microsatellites often generate stutter peaks that can mask other alleles and, secondly, shorter alleles can be preferentially amplified (Daniels et al., 1998). In our PCR assays, these drawbacks 


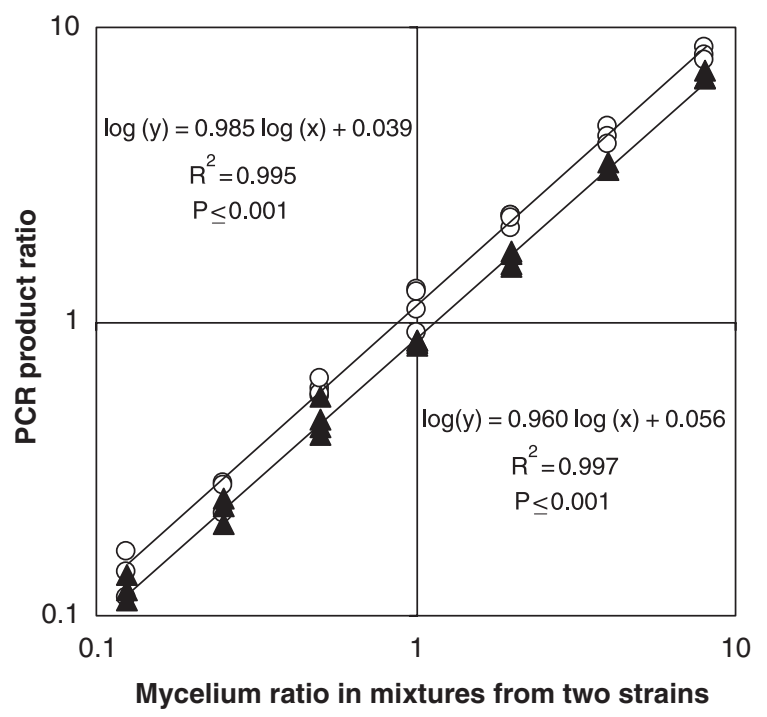

Fig. 2. Standard curves for the quantification of Fusarium graminearum GZ3639 ( $\mathbf{\Delta}$ ) and Trichoderma atroviride P1 (o) with competitive microsatellite PCR. Lyophilized mycelia of F. graminearum GZ3639 and F. graminearum 9701 and, correspondingly, mycelia of $T$. atroviride P1 and T. harzianum RAC616 were mixed in different ratios each in three replicates. The ratio of strain-specific PCR products is plotted on a logarithmic scale against the ratio of mycelia in standard mixtures. The lower equation describes the linear regression through $\mathrm{PCR}$ product ratio of the Fusarium-specific microsatellite MS-Fg103 (peak height of GZ3639 divided by peak height of 9701). The upper equation describes the linear regression through PCR product ratio of the Trichodermaspecific microsatellite MS-Ta4 (peak height of P1 divided by peak height of RAC616).

were circumvented by selection of microsatellites without considerable stutter and selection of reference strains of similar fragment length. Moreover, a slightly preferential amplification of reference or target allele equally affects the measured target/reference ratio in samples and standard mixtures and therefore is included in the assay calibration. Our PCR assays were designed to monitor two specific strains but they can also be used for other strains of F. graminearum or T. atroviride or closely related species. For example, the microsatellite MS-Fg103 assay was also used to quantify the biomass of the Swiss F. culmorum strain 9713 on maize residues (A. Naef, unpublished data). Our competitive microsatellite PCR could be used to quantify specific strains in field samples (Figs $3 a$ and c) but this application requires preliminary identification of prevalent microsatellite alleles to select a reference strain with distinct allele.

\section{Comparison with real-time PCR}

To compare reproducibility and recovery of the novel competitive microsatellite PCR with real-time PCR, a known amount of target biomass was assessed in mixtures with different nontarget materials. The mixtures for realtime PCR were identical except for the omission of reference spiking. Extracted DNA was quantified with a DNA-binding fluorescent dye from samples without reference mycelium (Table 2). The presence of autoclaved maize leaves and partially decomposed overwintered maize stalks decreased the total DNA yield. This decrease was significant for $F$. graminearum mycelium mixed with partially decomposed maize tissue (Table 2). Addition of air-dried maize leafs and nontarget mycelium increased the total DNA yield. The competitive microsatellite PCR assays for T. atroviride P1 and F. graminearum GZ3639 were not affected by any nontarget material and recovered completely the target mycelia (Figs 3a and c). Conversely, the real-time PCR assays showed decreased recovery of target mycelia in the presence of nontarget material (Figs $3 \mathrm{~b}$ and $\mathrm{d}$ ). Overall variation was lower with the competitive microsatellite PCR (standard error, SE $=0.08 \mathrm{mg}$ with MS-Fg103 and $\mathrm{SE}=0.06 \mathrm{mg}$ with MS-Ta4) than with real-time PCR $(\mathrm{SE}=0.34 \mathrm{mg}$ with $\mathrm{MS}-\mathrm{Fg} 103$ and $\mathrm{SE}=0.58 \mathrm{mg}$ with MS-Ta4).

Quantitative PCR assays without internal standards such as the real-time assays used, rely on constant extraction and amplification efficiency of target DNA. However, less DNA was extracted from a mixture of $F$. graminearum mycelium with decomposed plant tissue than from mycelium alone (Table 2), suggesting that the extraction efficiency of fungal target DNA is affected by the presence of decomposing plant tissue. The low real-time PCR biomass recovery in the presence of decomposed plant tissue and other nontarget materials (Figs $3 \mathrm{~b}$ and $\mathrm{d}$ ) indicates that the amplification efficiency of target DNA was also not constant. The nontarget materials must have released PCR-inhibiting substances that were coextracted with the DNA (Wilson, 1997). Commonly used standardization approaches for PCR quantification of fungi in living plant parts, such as normalization of total DNA concentration before PCR (Nicholson et al., 1998; Edwards et al., 2001) or coamplification of plant DNA sequences (Winton et al., 2002), assume a constant amount of extractable plant DNA. In samples with decomposing plant material, this assumption is compromised by the degradation of plant DNA. Our novel PCR assays use the DNA of a spiked reference strain as internal standard for variation in DNA extraction and variation in PCR amplification and therefore are not affected by the variable DNA content and the presence of PCR inhibitors in decomposing plant material such as field-overwintered maize residues.

The range of quantification with our PCR assays depends on the amount of spiked reference mycelium and therefore is limited by the range of accurate weighing. With our equipment and the described external and internal standards, it was possible to accurately quantify fungal biomass 
Fig. 3. Influence of $24 \mathrm{mg}$ of different nontarget material on the detection of $6 \mathrm{mg}$ fungal mycelium by quantitative PCR assays. Trichoderma atroviride P1 was quantified with Trichoderma-specific primers of the microsatellite MS-Ta4 using competitive microsatellite PCR

(a) and using real-time PCR with SYBR ${ }^{\circledR}$ Green (b). Fusarium graminearum GZ3639 was quantified with Fusarium-specific primers of the microsatellite MS-Fg103 using competitive microsatellite PCR (c) and using real-time PCR with SYBR ${ }^{\circledR}$ Green (d). Values are means of three replicate mixtures $( \pm S D)$. Bars with different letters above them are significantly different according to Fisher's LSD test $(P \leq 0.05)$.

from 0.01 to $0.8 \mathrm{mg}(\mathrm{mg} \text { dry sample })^{-1}$ in samples of approximately $25 \mathrm{mg}$ dry weight. A lower detection range can be achieved by increasing the sample weight with an unaltered amount of spiked reference mycelium. The quantitative range of two orders of magnitude is narrow compared to the five orders of magnitude achieved with real-

Table 2. Total DNA extracted from $6 \mathrm{mg}$ freeze-dried mycelium of either Fusarium graminearum GZ3639 or Trichoderma atroviride P1 mixed with $24 \mathrm{mg}$ of different non-target material

\begin{tabular}{|c|c|c|}
\hline \multirow[b]{2}{*}{ Nontarget material } & \multicolumn{2}{|c|}{ Total DNA yield* $(\mu \mathrm{g})$} \\
\hline & $\begin{array}{l}\text { Mixed with } F \text {. } \\
\text { graminearum } \\
\text { GZ3639 }\end{array}$ & $\begin{array}{l}\text { Mixed with } T \text {. } \\
\text { atroviride P1 }\end{array}$ \\
\hline None (pure target mycelium) & $3.82 \pm 0.70 b$ & $2.72 \pm 0.20 \mathrm{a}$ \\
\hline Autoclaved maize leafs & $2.47 \pm 1.12 \mathrm{ab}$ & $2.22 \pm 0.76 a$ \\
\hline Freeze-dried maize leaves & $10.74 \pm 1.89 c$ & $8.05 \pm 2.36 b$ \\
\hline Mycelium of nontarget fungus ${ }^{\dagger}$ & $15.00 \pm 1.29 d$ & $17.26 \pm 1.17 c$ \\
\hline Field-overwintered maize residues ${ }^{\ddagger}$ & $1.68 \pm 0.51 a$ & $2.22 \pm 0.34 a$ \\
\hline
\end{tabular}

*Extracted DNA was quantified with the fluorescent DNA stain PicoGreen ${ }^{\circledR}$. Values represent means ( \pm standard deviation) of three replicate mixtures. Values within a column followed by different letters are significantly different according to Fisher's LSD test $(P \leq 0.05)$.

†Nontarget mycelium was from $T$. atroviride $\mathrm{P} 1$ and $F$. graminearum GZ3639, respectively.

${ }^{\ddagger}$ Maize stalks from the previous year were collected in spring. time PCR assays (Edwards et al., 2002; McCartney et al., 2003), but our microsatellite-based competitive PCR assays showed a lower variability than real-time PCR assays within the range of interest.

\section{Role of Fusarium graminearum DON production in the interaction with the antagonist Trichoderma atroviride}

The novel PCR assays were used to test whether DON synthesis by F. graminearum is involved in the fungal defense against the biocontrol agent $T$. atroviride on autoclaved maize leaf pieces mimicking postharvest maize residues. Preliminary experiments have shown that the natural microflora varies between leaves and leaf pieces, which affected the growth of the two inoculated fungi in microcosms. We autoclaved the maize leaf tissue to obtain reproducible conditions because surface-sterilization could not completely remove the natural microflora. Autoclaving, however, modifies tissue composition, potentially affecting the fungal interaction. T. atroviride strain P1 was confronted with either the wild-type F. graminearum strain GZ3639 or the insertional mutant GZT40 (Proctor et al., 1995) lacking DON production. We let the antagonists competitively colonize the maize tissue and observed mutual intermingling of mycelia after 5 days of incubation. Fungal biomass 
and DON levels were quantified after 10 days (Table 3). The biomasses of the two F. graminearum strains were significantly reduced in the presence of T. atroviride P1 (15\% and $16 \%$ reduction of GZ3639 and GZT40, respectively) but the biomass of the biocontrol agent itself was reduced even more $(50 \%$ and $55 \%$ reduction by GZ3639 and GZT40, respectively). None of the biomass differences between microcosms with DON-producing wild-type $F$. graminearum GZ3639 and atoxigenic mutant GZT40 was significant. DON was detected only in microcosms with the wild-type $F$. graminearum GZ3639. The measured concentrations were significantly reduced in the presence of $T$. atroviride P1 (Table 3). The mean DON reduction of $45 \%$ exceeded the mean GZ3639 biomass reduction of 15\%. Consequently, the mean DON production per biomass of GZ3639 was significantly lower (36\%) in joint culture with T. atroviride than in solitary culture (Table 3).

Our quantification of fungal biomass showed that DON reduction resulted only in part from a biomass reduction of F. graminearum, suggesting that presence of $T$. atroviride $\mathrm{P} 1$ affects DON synthesis in F. graminearum GZ3639. A previous report of reduced DON levels in agar tube assays with F. graminearum and T. harzianum (Cooney et al., 2001) could not separate biosynthesis reduction from biomass reduction because fungal biomass was not quantified. An alternative explanation for reduced DON concentrations would be DON degradation by Trichoderma, but strain P1 was not able to degrade synthetic DON in malt extract medium (A. Naef, unpublished data), nor could the $T$. harzianum strain used in the tubular bioassays metabolize DON (Cooney et al., 2001). The ability to degrade DON under aerobic conditions generally seems to be rare in the microbial community (Völkl et al., 2004). It remains to be shown whether the repression of DON synthesis is Tricho- derma-mediated or a general phenomenon that results from crowding with any antagonist. If T. atroviride actively also reduces DON synthesis in an agricultural setting, this could offer a biocontrol strategy to reduce DON levels in crop residues.

In contrast to our observations, stimulation of $F$ graminearum DON production was reported in the competition with Fusarium verticillium or Fusarium proliferatum on irradiated maize kernels (Velluti et al., 2001). Fungal biomasses were not quantified in this study, and it is possible that higher DON levels resulted from a stimulated $F$. graminearum growth. However, the authors suggested that DON production is a defense strategy of F. graminearum. This hypothesis was further supported by a report of DONmediated repression of the biocontrol gene nag1 in $T$. atroviride P1 (Lutz et al., 2003). The encoded Nag1 N-acetylglucosaminidase degrades chitin in fungal cell walls and is relevant to biocontrol of fungi (Brunner et al., 2003). Yet, we found no significant differences in the fungal biomasses in the comparison between F. graminearum GZT40 with interrupted DON synthesis and wild-type F. graminearum strain GZ3639 (Table 3). This indicates that DON production did not provide the wild type with a competitive advantage against $T$. atroviride, although the DON level in the presence of T. atroviride ( $42 \mathrm{ng} \mathrm{mg}^{-1}$ ) exceeds the levels which Lutz et al. (2003) reported to cause nagl gene repression (1-5 $\left.\mathrm{ng} \mathrm{mg}^{-1}\right)$. Other biocontrol genes in T. atroviride P1 which are not affected by the presence of DON, like the endochitinase gene ech42 (Lutz et al., 2003), may compensate for the loss of one enzyme involved in its biocontrol activity. The low competing ability of T. atroviride P1 in our microcosm further suggests that substrate competition is more important than mycoparasitism in the saprophytic interaction between these two fungi.

Table 3. The biomasses of Trichoderma atroviride strain P1, Fusarium graminearum strain GZ3639 (DON ${ }^{+}$wild type), or F. graminearum strain GZT40 (DON ${ }^{-}$mutant), the mycotoxin DON content of samples, and the DON production per $F$. graminearum biomass after individual and competitive colonization of maize tissue*

\begin{tabular}{|c|c|c|c|c|}
\hline \multirow[b]{2}{*}{ Fungal strain(s) } & \multicolumn{2}{|c|}{$\begin{array}{l}\text { Fungal biomass } \\
\text { ( } \mu \text { g per mg sample) }\end{array}$} & \multirow{2}{*}{$\begin{array}{l}\text { DON content }{ }^{\ddagger} \\
\text { (ng per mg sample) }\end{array}$} & \multirow{2}{*}{$\begin{array}{l}\text { DON production } \\
\text { (pg per mg } \\
\text { F. graminearum) }\end{array}$} \\
\hline & T. atroviride & F. graminearum & & \\
\hline F. graminearum $\mathrm{DON}^{+}$alone & & $284 \pm 9 a$ & $76.9 \pm 7.3 a$ & $279 \pm 25 a$ \\
\hline F. graminearum $\mathrm{DON}^{-}$alone & & $297 \pm 12 a$ & $\mathrm{BDL}^{\bullet}$ & \\
\hline T. atroviride alone & $366 \pm 39 a$ & & $\mathrm{BDL}$ & \\
\hline T. atroviride and F. graminearum $\mathrm{DON}^{+}$ & $178 \pm 17 b$ & $241 \pm 15 b$ & $42.4 \pm 5.6 b$ & $179 \pm 23 b$ \\
\hline T. atroviride and $F$. graminearum $\mathrm{DON}^{-}$ & $149 \pm 16 b$ & $250 \pm 11 b$ & $\mathrm{BDL}$ & \\
\hline
\end{tabular}

*Agar plugs of the fungi were placed at opposite ends of an autoclaved leaf piece and incubated for 10 days at $24^{\circ} \mathrm{C}$.

'Biomass of fungi was measured with competitive microsatellite PCR. Values are means ( \pm standard error of mean) of three experiments with six replicates per experiment. Values within a column followed by different letters are significantly different according to Fisher's LSD test $(P \leq 0.05)$. ${ }^{\ddagger}$ DON content was measured with quantitative ELISA. Values and statistics as described in ${ }^{\dagger}$

${ }^{\S}$ DON production was calculated for each replicate in relation to $F$. graminearum biomass. Values and statistics as described in ${ }^{\dagger}$.

"BDL, below detection limit of $0.2 \mathrm{ng}$ per mg sample. 
We did not expect such a low competitiveness of $T$. atroviride $\mathrm{P} 1$ because in vitro tests on malt extract and potato dextrose agar showed faster mycelial growth of T. atroviride P1 than of F. graminearum GZ3639 at the chosen temperatures (A. Naef, unpublished data). Furthermore, Lutz et al. (2003) report no effect of Fusarium strains, including GZ3639, on the growth of T. atroviride P1 in confrontation assays on malt extract agar. The visual quantification of fungal growth on agar plates (measurement of mycelium area Lutz et al., 2003) that was used is difficult for intermingling fungi and may have misinterpreted their interaction. Furthermore, agar plates and maize tissue differ in many properties that could affect the interaction. Differences in water activity, for example, have been shown to affect the competing abilities of F. graminearum and Trichoderma (Marin et al., 1998). Our microcosm design and the presented PCR assays offer a system to screen Trichoderma spp. for better performance against $F$. graminearum than $T$. atroviride $P 1$. We would point out that our microcosms cannot replace subsequent field trials with maize residues, because discrepancy between in vitro tests and the performance in biological control is a common problem and has been reported for Trichoderma in the control of wheat seedling blight caused by F. graminearum (Dal Bello et al., 2002).

In conclusion, the competitive microsatellite PCR assays presented here allowed reliable biomass quantification of T. atroviride and F. graminearum in samples which contained a variable amount of DNA and PCR inhibitors, such as air-dried maize leaves and field-overwintered maize residues. Competitive microsatellite PCR could have applications for the quantification of other fungi, particularly under conditions where real-time PCR performs poorly. We used our PCR assays to test the competitive ability of a DON-producing F. graminearum and its nontoxigenic mutant against the biocontrol candidate $T$. atroviride in a standardized microcosm with autoclaved maize leaf tissue. As we found no evidence for a recently suggested competitive advantage conferred by F. graminearum DON production (Velluti et al., 2001; Lutz et al., 2003), biocontrol application of Trichoderma is unlikely to increase selection for toxigenic F. graminearum specimens; this needs to be proven under field conditions. In our competition assays, we further observed partially reduced DON production per F. graminearum wild-type biomass in the presence of T. atroviride. The role of T. atroviride in this DON reduction and a potential biocontrol application require further investigation. Although we found no evidence for DON production as a defense strategy against antagonism, one should be careful drawing the conclusion that DON has no relevance in the saprophytic stage of Fusarium. DON is a potent inhibitor of eukaryotic protein synthesis (Bennett \& Klich, 2003) and toxic to insect cells (Fornelli et al., 2004), so it may potentially affect any other decomposer of crop residues, including arthropods.

\section{Acknowledgments}

We gratefully acknowledge B. Koller (ECOGENICS GmbH, Zurich, Switzerland) for assistance in microsatellite development, A. Paolo (Torrey Mesa Research Institute, Syngenta, San Diego, CA) for identification of simple sequence repeats in the F. graminearum genome database, K. O'Donnell (ARS culture collection, USDA) for providing F. graminearum strains, M. Lorito for providing the T. atroviride strain, M. Maurhofer and P. Ceresini for reading the manuscript. This research was supported by Swiss National Center of Competence in Research (NCCR Plant Survival, Neuchâtel).

\section{References}

Bennett JW \& Klich M (2003) Mycotoxins. Clin Microbiol Rev 16: 497-511.

Bluhm BH, Cousin MA \& Woloshuk CP (2004) Multiplex real-time PCR detection of fumonisin-producing and trichothecene-producing groups of Fusarium species. J Food Prot 67: 536-543.

Bottalico A \& Perrone G (2002) Toxigenic Fusarium species and mycotoxins associated with head blight in small-grain cereals in Europe. Eur J Plant Pathol 108: 611-624.

Broder MW \& Wagner GH (1988) Microbial colonization and decomposition of corn, wheat, and soybean residue. Soil Sci Soc Am J 52: 112-117.

Brunner K, Peterbauer CK, Mach RL, Lorito M, Zeilinger S \& Kubicek CP (2003) The Nag1 $N$-acetylglucosaminidase of Trichoderma atroviride is essential for chitinase induction by chitin and of major relevance to biocontrol. Curr Genet 43: 289-295.

Cooney JM, Lauren DR \& di Menna ME (2001) Impact of competitive fungi on trichothecene production by Fusarium graminearum. J Agric Food Chem 49: 522-526.

Dal Bello GM, Monaco CI \& Simon MR (2002) Biological control of seedling blight of wheat caused by Fusarium graminearum with beneficial rhizosphere microorganisms. World J Microbiol Biotechnol 18: 627-636.

Daniels J, Holmans P, Williams N, Turic D, McGuffin P, Plomin R \& Owen MJ (1998) A simple method for analyzing microsatellite allele image patterns generated from DNA pools and its application to allelic association studies. Am J Hum Genet 62: 1189-1197.

Dill-Macky R \& Jones RK (2000) The effect of previous crop residues and tillage on Fusarium head blight of wheat. Plant Dis 84: 71-76.

Dodd SL, Lieckfeldt E \& Samuels GJ (2003) Hypocrea atroviridis sp nov., the teleomorph of Trichoderma atroviride. Mycologia 95: 27-40. 
Edwards SG, Pirgozliev SR, Hare MC \& Jenkinson P (2001) Quantification of trichothecene-producing Fusarium species in harvested grain by competitive PCR to determine efficacies of fungicides against Fusarium head blight of winter wheat. Appl Environ Microbiol 67: 1575-1580.

Edwards SG, O'Callaghan J \& Dobson ADW (2002) PCR-based detection and quantification of mycotoxigenic fungi. Mycol Res 106: 1005-1025.

Fernandez MR (1992) The effect of Trichoderma harzianum on fungal pathogens infesting wheat and black oat straw. Soil Biol Biochem 24: 1031-1034.

Fornelli F, Minervini F \& Mule G (2004) Cytotoxicity induced by nivalenol, deoxynivalenol, and fumonisin B, in the SF-9 insect cell line. In Vitro Cell Dev Biol Anim 40: 166-171.

Hjeljord L \& Tronsmo A (1998) Trichoderma and Gliocladium in biological control: an overview. Enzymes, Biological Control and Commercial Applications, Vol. 2 (Harman GE \& Kubicek CP, eds), pp. 129-151. Taylor \& Francis, London.

Kullnig CM, Krupica T, Woo SL, Mach RL, Rey M, Benitez T, Lorito M \& Kubicek CP (2001) Confusion abounds over identities of Trichoderma biocontrol isolates. Mycol Res 105: 770-772.

Li YC, Korol AB, Fahima T, Beiles A \& Nevo E (2002) Microsatellites: genomic distribution putative functions and mutational mechanisms: a review. Mol Ecol 11: 2453-2465.

Lutz MP, Feichtinger G, Défago G \& Duffy B (2003) Mycotoxigenic Fusarium and deoxynivalenol production repress chitinase gene expression in the biocontrol agent Trichoderma atroviride P1. Appl Environ Microbiol 69: 3077-3084.

Marin S, Companys E, Sanchis V, Ramos AJ \& Magan N (1998) Effect of water activity and temperature on competing abilities of common maize fungi. Mycol Res 102: 959-964.

McCartney HA, Foster SJ, Fraaije BA \& Ward E (2003) Molecular diagnostics for fungal plant pathogens. Pest Manag Sci 59: 129-142.

McMullen M, Jones R \& Gallenberg D (1997) Scab of wheat and barley: a re-emerging disease of devastating impact. Plant Dis 81: 1340-1348.

Nicholson P, Simpson DR, Weston G, Rezanoor HN, Lees AK, Parry DW \& Joyce D (1998) Detection and quantification of Fusarium culmorum and Fusarium graminearum in cereals using PCR assays. Physiol Mol Plant Pathol 53: 17-37.
Proctor RH, Hohn TM \& McCormick SP (1995) Reduced virulence of Gibberella zeae caused by disruption of a trichothecene toxin biosynthetic gene. Mol Plant-Microbe Interact 8: 593-601.

Reischer GH, Lemmens M, Farnleitner A, Adler A \& Mach RL (2004) Quantification of Fusarium graminearum in infected wheat by species specific real-time PCR applying a TaqMan Probe. J Microbiol Methods 59: 141-146.

Rozen S \& Skaletskyand HJ (2000) Primer3 on the WWW for general users and for biologist programmers. Bioinformatics Methods and Protocols: Methods in Molecular Biology (Krawetz S \& Misener S, eds), pp. 365-386. Humana Press, Totowa, NJ, USA.

Schnerr H, Niessen L \& Vogel RF (2001) Real time detection of the tri5 gene in Fusarium species by LightCycler ${ }^{\text {TM }}$-PCR using SYBR ${ }^{\circledR}$ Green I for continuous fluorescence monitoring. Int $J$ Food Microbiol 71: 53-61.

Sutton JC (1982) Epidemiology of wheat head blight and maize ear rot caused by Fusarium graminearum. Can J Plant Pathol 4: 195-209.

Tenzer I, degli Ivanissevich S, Morgante M \& Gessler C (1999) Identification of microsatellite markers and their application to population genetics of Venturia inaequalis. Phytopathology 89: 748-753.

Völkl A, Vogler B, Schollenberger M \& Karlovsky P (2004) Microbial detoxification of mycotoxin deoxynivalenol. J Basic Microbiol 44: 147-156.

Velluti A, Marin S, Gonzalez R, Ramos AJ \& Sanchis V (2001) Fumonisin $B_{1}$, zearalenone and deoxynivalenol production by Fusarium moniliforme, $F$. proliferatum and $F$. graminearum in mixed cultures on irradiated maize kernels. J Sci Food Agric 81: 88-94.

Waalwijk C, van der Heide R, de Vries I, et al. (2004) Quantitative detection of Fusarium species in wheat using TaqMan. Eur J Plant Pathol 110: 481-494.

Wilson IG (1997) Inhibition and facilitation of nucleic acid amplification. Appl Environ Microbiol 63: 3741-3751.

Windels CE \& Kommedahl T (1984) Late-season colonization and survival of Fusarium graminearum Group-I in cornstalks in Minnesota. Plant Dis 68: 791-793.

Winton LM, Stone JK, Watrud LS \& Hansen EM (2002) Simultaneous one-tube quantification of host and pathogen DNA with real-time polymerase chain reaction.

Phytopathology 92: 112-116. 